\title{
Efetividade histórica e ciência moral nas Décadas de João de Barros: a relação entre antigos e modernos
}

Rubens Leonardo Panegassi

Resumo: O objetivo deste artigo é revisitar o tema da querela entre antigos e modernos a partir das Décadas da Ásia, obra de autoria do humanista português João de Barros. Publicada entre os anos de 1552 e 1563, essa obra pode ser compreendida como a mais notória tentativa de definir um sentido global para o fenômeno dos descobrimentos marítimos portugueses. Entretanto, ao tratar das origens e do amadurecimento do processo de expansão marítima em Portugal, as Décadas da Ásia remete-nos também aos primórdios da vertente ibérica do embate entre antigos e modernos. Em vista disso, nosso interesse é recuperar essa querela no âmbito da relação que João de Barros institui entre antigos e modernos, como pressuposto do pensamento histórico no alvorecer da Época Moderna.

Palavras-chave: História da historiografia. Humanismo. João de Barros. Antigos e Modernos. Portugal.

\section{Introdução}

João de Barros é um autor com o qual necessariamente nos deparamos ao nos debruçarmos sobre a produção historiográfica elaborada no contexto da expansão marítima e do Renascimento em Portugal. Bastardo nobilitado na Corte, os cargos que ocupou ligam-no diretamente não apenas ao Rei e à família real, mas também

\footnotetext{
* Graduado, mestre e doutor em História pela Universidade de São Paulo, foi bolsista da FAPESP e é professor de História Moderna e Contemporânea da Universidade Federal de Viçosa desde 2013. Financiamento: FAPESP. E-mail: rubenspanegassi@gmail.com.
} 
aos altos dignitários e financistas do reino ibérico, situação que alçou este "nobre de pluma" a uma situação bastante privilegiada no que diz respeito aos negócios e aos feitos portugueses na Ásia. Moralista profícuo foi decano da "Geração de Quinhentos" do humanismo português (MENDES, 1998), ${ }^{1}$ e a multiplicidade de sua obra o situa "entre as figuras mais salientes da historiografia portuguesa sobre a expansão marítimo-mercantil” (BARRETO, 1998, p. 121). Sem dúvida, o fato de esta temática ter sido considerada oportunamente a historiografia portuguesa tout court garante especial relevância às Décadas de João de Barros, não apenas enquanto obra emblemática do alvorecer da Época Moderna, mas também como evidência eloquente dos embates e das disputas sobre a imposição de sentidos à própria constituição do império português, campo de estudos em torno do qual são numerosas as questões e a bibliografia, inesgotável.

Por sua vez, a publicação das Décadas teve início com a "primeira década", cujo título aparece como Ásia de João de Barros, dos feitos que os portugueses fizeram no descobrimento e conquista dos mares e terras do Oriente, editada em 1552. A "segunda década" foi editada em 1553, ou seja, apenas um ano depois de publicar a "primeira década", ao passo que a "terceira década" só conheceria a prensa dez anos após a publicação da Segunda década da Ásia de João de Barros, em 1563. Por fim, haveria uma quarta Década, para a qual João de Barros chegou a escrever o prólogo, mas que ficou inacabada. Essa "quarta década" foi reformada por João Batista Lavanha a pedido de Filipe II e publicada em 1615. Em suma, se entre 1552 e 1563 João de Barros escreveu e esteve presente na edição das três primeiras Décadas, o mesmo não aconteceu quando a "quarta década" veio à luz, em 1615, de modo que não é possível reconhecê-la como uma obra composta por João de Barros. ${ }^{2}$

Em linhas gerais, é notável que a elaboração das Décadas se define tanto a partir da perspectiva humanista de João de Barros quanto de sua tentativa de sintetizar a expansão portuguesa. Nesse sentido, as Décadas tratam das navegações marítimas e daquilo que pode ser entendido como a constituição do império português na Ásia, sobretudo à medida que propõe uma unidade de sentido "global" dos descobrimentos. Tendo em vista a perspectiva do cronista em retratar os feitos portugueses no descobrimento e na conquista do 
oriente, é possível notar a dimensão cronológica dessa narrativa de modo sumário: a "primeira década" tem início com as viagens de descobrimento na costa ocidental da África ainda no século XV e culmina com a inserção comercial e militar dos portugueses na Ásia, já no século XVI. Por sua vez, a "segunda década" trabalha com uma temporalidade reduzida em relação à primeira e dedica seis livros aos feitos de Afonso de Albuquerque, até sua morte. Por fim, a "terceira década" é composta, ainda, pelos feitos ligados à administração e consolidação do poder português na Ásia, entretanto, vários são os personagens unidos pela trama narrativa dos livros, entre eles, Lopo Soares de Albergaria, Diogo Lopes de Sequeira, Duarte de Meneses, Vasco da Gama e Henrique de Meneses.

Em síntese, João de Barros trata das origens do processo expansionista até o momento de sua maturação. Sem dúvida, as Décadas remete-nos a uma atmosfera política de conquistas fundamentadas, acima de tudo, no nome da cristandade, o que permitiu a João de Barros descrever "[...] todos os 'feitos que os portugueses fizeram no descobrimento e conquista dos mares e terras do oriente' como um prolongamento da Reconquista" (THOMAZ; ALVES, 1991, p. 127). Todavia, a obra magna do humanista português reporta-nos, também, a um notável embate entre antigos e modernos, que no reino luso incorpora tanto a vertente italiana que marca "os começos do movimento humanista em Portugal" quanto "as concepções pedagógicas e doutrinárias do humanismo norte-europeu” (PEREIRA, 2008, p. 94) - em conformidade com o erasmismo presente na Corte lusa. Efetivamente, ambas as tradições seriam operantes mediadores na percepção que os letrados do reino ibérico teriam da experiência ultramarina. É digno de nota, também, que a experiência portuguesa dos descobrimentos marítimos seria responsável pela associação de um terceiro elemento ao embate entre Antigos e Modernos: o Selvagem (HARTOG, 2005). De todo modo, cabe notar que a descoberta dos autores gregos e latinos, ocorrida ao longo dos séculos XIV e XV, seria fundamental para a codificação da escrita da história na Época Moderna (ALBANESE, 2009).

Com efeito, vale observar que a questão relativa aos antigos e modernos na obra de João de Barros já foi abordada por I. S. Révah em artigo clássico. Contudo, Révah debruçou-se, principalmente, sobre a presença do cristianismo primitivo nos escritos de 
caráter erasmiano da obra de Barros (RÉVAH, 1967). Aqui, ainda que nosso interesse seja revisitar a clássica querela, importa considerá-la, fundamentalmente, no âmbito da relação estabelecida entre antigos e modernos como pressuposto do pensamento histórico do início da Época Moderna.

\section{Antigos e modernos: efetividade histórica e ciência moral}

Quando atentamos para as Décadas de João de Barros, seu texto não pode deixar de ser compreendido como resultante de um momento que se concebe como uma época já distante da Antiguidade, um ambiente plenamente inserido no contexto da experiência histórica que, tal como sugeriu José Antonio Maravall, permitiu sua assimilação como uma categoria referente a um período histórico singular, concreto e, sobretudo, paradigmático (MARAVALL, 1986). Para o historiador espanhol, o homem da Época Moderna detém uma chave específica de leitura do tempo histórico, em que o desenvolvimento de um fio contínuo no curso do tempo é diferenciável em várias fases ou épocas. Ou seja, para ele, "[...] el factor de continuidad, en la medida que existe, permite contemplar el tiempo de las sociedades como un curso no interrumpido, pero que por su misma larga duración va llevando a situaciones diferentes unas de las otras" (MARAVALL, 1986, p. 285-286).

Sob esta perspectiva, é possível compreender o complexo fenômeno da recuperação e imitação da Antiguidade no contexto do Renascimento europeu. Reside sobretudo nesta consciência histórica o necessário distanciamento característico de um procedimento intelectual que, simultaneamente, atualiza e apropria-se de uma herança cultural cujas formulações nem sempre auxiliam na compreensão do mundo coevo. Com efeito, essas apropriações intelectuais são o resultado mais evidente dos contornos que o Renascimento adquiriu no âmbito de suas mais diversas manifestações, bem como de sua interação dentro dos mais diversos contextos. Segundo Jaques Le Goff, embora a relação entre antigos e modernos esteja profundamente ligada à história do ocidente, é possível encontrar equivalentes 
dela em outras civilizações e outras historiografias (LE GOFF, 2003). No que tange ao caso de Portugal, sua especificidade pode ser notada tanto na produção de uma literatura de caráter etnográfico, resultante do contato com a diversidade de povos e culturas ao longo de sua expansão marítima, quanto nos pressupostos que orientam a formação do humanismo quinhentista lusitano, em que a retórica seria incluída, paulatinamente, no plano de estudos oficial, até alcançar centralidade no âmbito das humanidades, superando a orgânica medieval que lhe atribuía modesta importância, como nota Aníbal Pinto de Castro:

[...] sem deixar de lhe imprimir um cunho literário bem vincado, o Humanismo faz da Retórica, ligando-a estreitamente à invenção dialética, a base de um método novo de filosofar que, desejoso de abandonar a especulação abstracta, procura aproximar-se da realidade humana através da comunicação, para tratar problemas actuais de índole moral, política, religiosa ou mesmo filosófica (CASTRO, 1973, p. 18).

Diante disso vale notar que a historiografia da época humanístico-renascentista seria compreendida, fundamentalmente, como ars rbetorica (ALBANESE, 2009), de modo que a retórica desempenharia um papel de absoluta relevância na aquisição do conhecimento crítico das letras humanas antigas, tal como sugeriu oportunamente Castro (1973). Por sua vez, a respeito da relação que a cultura europeia estabelece historicamente com o mundo clássico, Paul Hazard faz com que notemos que a Antiguidade permaneceria como modelo digno de admiração durante muito tempo, uma vez que "[...] tinham (a Antiguidade) dado ao mundo uma moral que o cristianismo não fez senão completar; na ação, tinham-se (os Antigos) comportado sempre como heróis" (HAZARD, 1948, p. 33). Dificilmente poderíamos concordar com a ideia de que o cristianismo "completou" a Antiguidade. De todo modo, o que importa sublinhar é a ideia de que, para viver, bastava imitar os antigos. Contudo, o predomínio dos antigos estava destinado a encontrar seu termo a partir do momento em que os modernos os destituíssem de seu lugar de honra e redefinissem a noção de moderno. 
Paulatinamente, assinala Hazard, “[...] abandonou-se o partido dos grandes mortos e deu-se a gente a alegria, aliás fácil e insolente, de sentir em si o afluxo duma vida nova, embora efêmera; preferiu-se apostar pelo presente a apostar pelo eterno" (HAZARD, 1948, p. 34). O autor faz notar, ainda, que esta viragem se deu a partir da querela dos antigos e modernos, célebre polêmica desencadeada por Charles Perrault e Bernard Le Bouyer de Fontenelle em oposição ao princípio de imitação dos clássicos. Por sua vez, Marc Fumaroli assinala que a polêmica desencadeada na França foi, na verdade, o auge de um embate cujo início remonta ao Renascimento, ou, mais precisamente, a Petrarca, quando este, orientado por seu desejo de recuperar as fontes antigas, denominou sob o qualificativo pejorativo - de "moderno" toda a ciência oriunda das faculdades de teologia e direito de sua época (FUMAROLI, 2001). Sobre o assunto, Iris Kantor assinala que os anos 1680-1715, propostos por Paul Hazard como decisivos para esta mudança da relação com a tradição herdada da Antiguidade, foram canonizados como data inicial do movimento iluminista (KANTOR, 2009).

Marc Fumaroli sugere que, desde o medievo, diversos foram os teólogos que fizeram uso da oposição entre antigos e modernos (FUMAROLI, 2001), ao passo que, segundo José Antonio Maravall, pode-se dizer que o gosto pela novidade é comum para a maioria dos escritores desde Ovídio. Entretanto o autor nota que, ao longo da história, a percepção do novo não se manifesta sempre da mesma maneira e por isso nem sempre se apresenta acompanhada das forças transformadoras que definem novos horizontes aos homens, tal como aconteceu na Época Moderna. Como apontamos anteriormente, o historiador espanhol faz notar que é a consciência da diversidade de épocas - ou, em suma, aquilo que poderíamos compreender como a percepção da sucessão de eventos articulados em um processo - que marcou o gosto pelo novo na primeira modernidade, sobretudo em face da possibilidade de estabelecer comparações entre as épocas (MARAVALL, 1986).

Com efeito, importa observar que, sobre a vertente ibérica da querela dos antigos e modernos, Íris Kantor atenta para a importância da expansão ultramarina na composição deste fenômeno. $\mathrm{Na}$ perspectiva da historiadora: 
As realidades criadas pela expansão europeia obrigavam à reconfiguração dos paradigmas geográficos, cronográficos e etnográficos herdados da Antiguidade. A descoberta da América motivara o sentimento de superioridade dos humanistas ibéricos em relação ao passado (KANTOR, 2009, p. 452-453).

É evidente que os modernos escolásticos criticados por Petrarca não são os mesmos modernos que reconfiguraram os paradigmas geográficos, cronográficos e etnográficos herdados da Antiguidade após os descobrimentos. Com efeito, nas Décadas, de João de Barros, é notória a existência da noção de moderno, ainda que a categoria não denote, necessariamente, superioridade em relação aos antigos. Notável exemplo é apresentado a nós pelo historiador quinhentista na "preparação de toda a obra quase em modo de argumento e divisão dela” (BARROS, 1778, p. 15), ${ }^{3}$ quando o autor assume que o empreendimento de sua narrativa demanda a evocação do triunfo sistemático dos reis portugueses contra os infiéis como fundamento dos três eixos que compõem o título da real coroa portuguesa que serão abordados em sua Ásia, a saber, a conquista, a navegação e o comércio. Por fim, escreve o humanista: "Deus é testemunha que em cada uma destas três partes, Conquista, Navegação e Comércio, fizemos a diligência possível a nós e mais do que a ocupação do ofício e profissão de vida nos tem dado lugar" (BARROS, 1778, p. 15). Com efeito, enquanto a conquista é própria da milícia e o comércio convém à mercadoria, por sua vez, ao título da navegação, anuncia, "[...] respondemos com uma universal Geografia de todo o descoberto, assim em graduação de tábulas como de comentário sobre elas, aplicando o moderno ao antigo, a qual não sofre compostura em linguagem, e por isso irá em latim” (BARROS, 1778, p. 14). ${ }^{4}$

Em sua geografia, portanto, haveria espaço para a relação dos descobrimentos "aplicando o moderno ao antigo", ou seja, atualizando as denominações herdadas dos antigos geógrafos por meio da inclusão dos nomes dos lugares que os portugueses incorporavam à sua carreira. Contudo, vale notar que as novas denominações viriam em latim, pois não era possível compô-las em língua vulgar. Com efeito, aqui, João de Barros veicula um dos pressupostos que seria 
estabilizado pelo "[...] mais completo tratado de retórica composto por um humanista português” (PEREIRA, 2008, p. 98), o De eloquentia, de Tomé Correia. Publicado em 1591, Correia também enfrentaria a questão da dinâmica da língua, tal como João de Barros. Segundo Belmiro Fernandes Pereira, Tomé Correia compreendia a língua "[...] como um organismo vivo que muda conforme as necessidades" (PEREIRA, 2008, p. 101), daí deriva que "[...] nomes não latinos podem ser empregues desde que se lhes dê forma latina como fazia César com os nomes gauleses" (PEREIRA, 2008, p. 101), resolução semelhante à adotada anos antes por João de Barros.

Por sua vez, essa dinâmica é flagrante na Ásia. Tal como pode-se notar nas ilhas do Cabo Verde, assim chamadas "[...] por comum nome [...] e pelos antigos geógrafos as Fortunadas, de que em a nossa Geografia falamos largamente" (BARROS, 1778, p. 140). O mesmo acontece com a Ilha Ceilão, "[...] a que os antigos chamam Taprobana" (BARROS, 1777c, p. 104), da qual nosso autor faz copiosa relação no primeiro capítulo do segundo livro da terceira Década. A dinâmica da língua decorria do contato e do registro dos lugares onde os portugueses fundariam fortalezas e portos, e obedecia à necessidade prática de situar com maior rigor as informações úteis, tal como se pode observar no princípio do sexto livro da segunda Década, onde nosso autor discute o erro dos antigos geógrafos, que, por desconhecimento da geografia local, chamavam a Ilha Sumatra de Quersoneso, que “[...] é palavra grega e se toma pela pequena partícula de terra pegada por tão delgada coisa como é o pé da folha da figueira pegada no ramo dela" (BARROS, 1777b, p. 2):

E porque geralmente todos os que navegavam por fora da Ilha, por ser viagem mais segura, ainda que comprida, estavam seguros de invernar como indo por dentro, ao modo que ora vemos os nossos navegantes daqui para a Índia, que quando partem tarde, vão por fora da Ilha de S. Lourenço por terem os tempos mais largos deste costume, com algumas fábulas que a Antiguidade sempre tem, assim como os perigos de Cila e Caribdis no trânsito de Sicília, bancos de Flandres entre a terra firme e a Ilha Inglaterra, ou os Baixos de Ceilão entre esta Ilha e a terra do Cabo Comorin, haveria opinião na Índia não ter aquele mar trânsito de Ponente a Levante, donde os gregos e Ptolomeu chamariam àquela terra Quersoneso.

Anos 90, Porto Alegre, v. 21, n. 39, p.165-197, jul. 2014 
Porém, povoada a cidade Malaca em meio daquele estreito [...] deu fácil navegação para se nela fazerem brevemente as comutações e comércio dos de Ponente e Levante, ficou manifesto este caminho, $e$ havida a terra de Sumatra por Ilha, e não Quersoneso (Idem, p. 14). ${ }^{5}$

Em suma, o problema linguístico suscitado pela atualização das denominações dos Antigos encontrou solução em um pressuposto que seria posteriormente estabilizado na pena de Tomé Correia a partir da Arte Poética, de Horácio (PEREIRA, 2008), o que denota um recurso epistemológico pautado na autoridade dos Antigos. Entretanto, este procedimento encontra-se, também, na esteira da experiência portuguesa e permite a superação de alguns erros cometidos pelos geógrafos antigos; vale notar que esta maneira de agir não era acompanhada, necessariamente, de uma conotação positiva. Sobretudo por estar potencialmente atrelada à cobiça. Em suma, não seria equivocado sugerirmos que, moralmente, os portugueses estavam aquém dos antigos quando movidos pela cobiça, assertiva que nos revela, sem dúvida, crítica aguda de nosso humanista aos interesses puramente materiais da expansão marítima:

A qual fica tão vizinha à terra de Malaca (a Ilha Sumatra), que no lugar mais estreito do canal que há entre elas não será mais que até doze léguas, quase na fronteira da cidade Malaca; dali, assim para a parte do Levante como Ponente, vai esta terra da Ilha afastando-se da firme, de maneira que faz estas duas entradas daquele estreito mais largo que no meio. E porém por todo ele tudo são baixos, restingas, ilhetas com canais, os quais errados, se perdem as naus que por ali navegam; e daqui (como atrás dissemos) procedeu, naquele antigo tempo de Ptolomeu e dos outros geógrafos, não ser aquele trânsito navegável como ora é, porque a cobiça dos homens todos os atalhos busca, ainda que perigosos, para conseguir seu intento (BARROS, 1777c, p. 506). ${ }^{6}$

Com efeito, atentemos para a particularidade da situação na qual João de Barros faz uso de seu juízo: um momento de reconfiguração de paradigmas, como sugeriu Íris Kantor. Por sua vez, em 
seu estudo sobre o pensamento político republicano, John G. A. Pocock atenta para o papel da prudência no âmbito das tomadas de decisão frente a situações sui generis. Desse modo, tendo em vista ser a prudência uma virtude que articula a capacidade individual racional - de julgar e a capacidade de cada indivíduo em fazer uso de toda experiência social acumulada - os costumes e as tradições - (POCOCK, 2008), importa considerar que o juízo de João de Barros também é pautado na prudência. Com isso, ao passo que ela nos remete a um julgamento, trata obrigatoriamente de uma situação presente, coeva, a qual, na esfera cognitiva, será combinada com a tradição. Nessa combinação é que antigo e moderno se articulam e estabelecem uma relação de reciprocidade que dá sentido a cada categoria diante da outra, em que o moderno, mediado pelo cristianismo estoico, é julgado por sua cobiça - ainda que o moderno possa nos remeter, também, aos feitos dos portugueses tidos por João de Barros como notáveis - enquanto o antigo, compreendido como experiência social acumulada, fornece um horizonte paradigmático de atuação que pode ser utilizado como elemento de comparação: embora tenham errado, Ptolomeu e os antigos geógrafos que designaram a Ilha de Sumatra como Quersoneso balizam de modo positivo a novidade da experiência, enquanto o ímpeto de realização movido pela "cobiça" é condenável e não pode servir de referência, nem pautar novas conquistas.

Como observou Jaques Le Goff, a "[...] atuação do antagonismo antigo/moderno é constituída pela atitude dos indivíduos, das sociedades e das épocas perante o passado, o seu passado" (LE GOFF, 2003, p. 175). Por isso, longe de ser estanque, essa combinação pode se configurar de maneiras diversas, em que o moderno pode superar o antigo, pois um fato absolutamente novo opera uma necessária reconfiguração dos referenciais, visto que não está inscrito no horizonte de experiências acumuladas. A efetividade histórica figura como clara demonstração de própria ciência moral, na qual a relação dos feitos deve estimular a virtude da prudência (GARIN, 1993). Daí a autonomia do juízo necessário às decisões ímpares e à reconfiguração dos paradigmas. A defesa deste procedimento revolucionário de autonomia intelectual é apresentada por nosso humanista em sua irônica apreciação das murmurações que 
fez o povo do reino contra os novos empreendimentos do Infante Dom Henrique, então estimulado pelo descobrimento da Madeira e dos Açores, os mais recentes sucessos de sua empresa:

Certamente nós não sabemos que opinião foi esta do Infante, nem que fruto ele espera deste seu descobrimento, senão perdição de quanta gente vai nos navios, para ficarem muitos órfãos e viúvas no reino, além da despesa de suas fazendas, pois o perigo e o gasto ambos estão manifestos e o proveito tão incerto, como todos sabemos. Porque sempre aí houve reis e príncipes em Espanha desejosos de grandes empresas, e tão cobiçosos de buscar e descobrir novos estados como o Infante, e não vemos nem lemos em suas crônicas que mandassem descobrir esta terra, tendo-a por tão vizinha. Mas como coisa de que não esperavam honra ou proveito algum deixaram de a descobrir, contentando-se com a terra que ora temos, a qual Deus deu por termo e habitação dos homens; e se alguma houver onde o Infante diz, devemos crer que ele a deixou para pasto dos brutos. Cá, segundo os antigos escreveram das partes do Mundo, todos afirmam que esta pela qual o sol anda a que eles chamam tórrida zona, não é habitada. Ora onde o Infante manda descobrir, é já tanto dentro no fervor do sol, que de brancos que os homens são, se lá for algum de nós, ficará (se escapar) tão negro como são os guinéus, vizinhos a esta quentura. Se ao Infante parece que, como ora achou estas duas ilhas que o tem mais elevado neste descobrimento, pode achar outras terras ermas, grossas e férteis, como dizem que elas são, terras e maninhos há no reino para romper e aproveitar sem perigo de mar, nem despesas desordenadas. E mais temos exemplos contrários a esta sua opinião, porque os reis passados deste reino sempre dos reinos alheios para o seu trouxeram gente a este a fazer novas povoações, e ele quer levar os naturais portugueses a povoar terras ermas por tantos perigos de mar, de fome e sede, como vemos que passam os que lá vão (BARROS, 1778, p. 27-38). ${ }^{7}$ 
A advertência das murmurações é plausível: o próprio João de Barros atentaria para o fato de que as coisas de grande admiração das conquistas do oriente deveriam ser ponderadas "com discurso de prudência", uma vez que a constante peleja dos expedicionários, seja com inimigos, seja com as forças da natureza, fazia com que sistematicamente se perdesse "uma nobre vila deste reino em substância de fazenda e em nobreza de gente" (BARROS, 1777b, p.152-153). De todo modo, podemos elencar três eixos que a opinião do infante não levou em consideração segundo as murmurações: o primeiro deles é de caráter mais "livresco", e nos remete à ausência de registros de empreendimentos similares bem sucedidos nas crônicas espanholas, bem como a opinião dos antigos sobre a zona tórrida; o segundo eixo, que abrange questões sociais, políticas e econômicas, remete-nos aos altos custos do empreendimento e às suas implicações na conservação do reino português, no qual existiam, ainda, maninhos a serem rompidos; o terceiro eixo, de caráter religioso, remete-nos à própria ordenação divina do mundo, que destinava uma parte dele para "habitação dos homens" e outra para "pasto dos brutos". Com efeito, a ironia de João de Barros é evidente, uma vez que ao escrever suas Décadas, João de Barros sabia que (ou queria acreditar nisso) os reis portugueses superaram todos os seus antecedentes na Península Ibérica em seus feitos e que a zona tórrida não produzia os efeitos nefastos que se acreditava; sabia também que a construção de um império transcontinental ampliaria a dignidade do reino português e, por fim, sabia que todo o mundo era habitado por homens, muito embora a maioria deles pudessem ser considerados, de fato, bárbaros, brutos e selvagens, mas que a salvação desses brutos era antes um bom motivo para a empresa do que o contrário.

A despeito do fato de que João de Barros chama nossa atenção para as irreparáveis perdas de fazenda e de gente, como um todo, nas Décadas, o humanista ocupa-se em mostrar que as murmurações estavam equivocadas, o que denota a efetiva modernidade da decisão do infante, bem como dos feitos portugueses. Não era, portanto, apenas aplicando o moderno ao antigo, ou corrigindo alguns de seus equívocos, que se desenhava a relação entre antigos e modernos. João de Barros mostra-nos que a experiência portuguesa descobriria coisas que, sequer, os antigos tiveram notícias, 
tal como se pode notar na representação que o autor nos dá de Dom João II e seu empenho na conquista da África, em que "[...] tão ocupado e solícito o trazia este negócio, principalmente depois que viu e gostou de muitas coisas de que os antigos escritores não tiveram notícia, falando desta parte da África, que não lhe repousava o espírito" (BARROS, 1778, p. 261).

Contudo, o desconhecimento e a falta de notícias por parte dos antigos era um evidente resultado de suas limitações técnicas. João de Barros não deixa de atentar para isso ao tratar do Mar Roxo, onde reprova "toda outra opinião de gregos e romanos", uma vez que "[...] não andaram com o astrolábio e sonda na mão por este e por todos os outros mares por que navegamos, como os nossos mareantes tem feito, e aceitamos esta cor vermelha ser por causa do lastro da terra” (BARROS, 1777b, p. 264). Sem dúvida, a percepção dos antigos por meio de "faltas" implica uma conotação defectiva: a falta da sonda e do astrolábio coloca os antigos no plano da inferioridade técnica. Sérgio Buarque de Holanda faz com que notemos que os portugueses inauguraram novos caminhos ao pensamento científico "[...] pelo simples fato de terem desterrado alguns velhos estorvos ao seu progresso" (HOLANDA, 2000, p. 12). Entretanto, as ausências que impediram os antigos de singrar os mares percorridos pelos portugueses não os detratavam absolutamente, uma vez que, embora não tenha tido oportunidade, os antigos teriam desejado saber a respeito das descobertas lusitanas:

Toda a terra que contamos por reino de Sofala, é uma grande região que senhoreia um príncipe gentio chamado Benomotapa, a qual abraçam em modo de ilha dois braços de um rio que procede do mais notável lago que toda a terra da África tem, muito desejado de saber dos antigos, escritores, por ser a cabeça escondida do ilustre Nilo, donde também procede o nosso Zaire, que corre pelo reino de Congo (BARROS, 1777, p. 372). ${ }^{8}$

O mistério sobre a nascente do rio Nilo permaneceu no imaginário letrado português ainda no século XVI. É novamente Sérgio Buarque de Holanda quem atenta para a crença de que suas águas 
proviessem do Paraíso Terreal (HOLANDA, 2000). Por sua vez, a despeito da imprecisão da tese de que a nascente do Rio Nilo fosse o "[...] mais notável lago que toda a terra da África tem [...]", na pena do humanista, os portugueses podiam saber - ou acreditavam poder saber - com perfeição a respeito daquilo que os antigos gostariam de ter sabido, mas não tiveram oportunidade, ou apenas puderam saber de modo imperfeito e confuso. É ainda nesta chave de leitura que João de Barros escreve sobre a Baía de Bengala, onde os "[...] cabos e ilhas são das mais notáveis partes que a India tem, e que antes de nosso descobrimento de alguma maneira eram sabidas e notas aos antigos geógrafos, ainda que por modo confuso" (BARROS, 1777c, p. 154).

Ora de modo confuso, ora como desejo, entre os antigos, o saber e a novidade ocupavam espaço relevante na pena de João de Barros. De fato, como sugere Le Goff, "[...] as sociedades históricas, mesmo que não se tenham apercebido da amplitude das mutações que viviam, experimentaram o sentimento de moderno" (LE GOFF, 2003, p. 176). Sobre o assunto, Luís Filipe Barreto sugere que os antigos são, "[...] no Renascimento, ainda saber, mas já não o saber". Para ele, uma característica do conceito de antigos é o "peso do horizonte informativo", em que a herança é um "horizonte de dados" (BARRETO, 1986, p. 88-89). Em suma, anota o autor:

A aceitação da herança passa, contudo, na lógica textual do renascentista, por um processo de encenação. O pólo da aceitação inscreve-se bem mais silenciosamente que o da rejeição. O renascentista aceita mais do que rejeita, no entanto, coloca sempre a aceitação na penumbra ou na sombra do plano textual guardando as luzes da ribalta para a rejeição (BARRETO, 1986, p. 89).

Sem dúvida, é possível atrelar a tese de que "[...] o renascentista aceita mais do que rejeita [...]" (Idem) a herança da Antiguidade, à ideia de que ao menos existira uma vontade de saber e que isto, por si, era uma virtude dos antigos. Ainda que o distanciamento em relação aos antigos fosse um fato, tal como apontamos oportunamente, havia uma pretensa continuidade entre os antigos e os 
modernos portugueses. Em síntese, supunha-se uma linearidade histórica em que os portugueses tiveram seus méritos ao lado dos romanos, fato evidente na pena de João de Barros ao longo da apresentação do projeto de sua milícia, que haveria de começar no "[...] tempo que os romanos conquistaram Espanha, na qual guerra os portugueses por feitos ilustres tiveram grande nome acerca deles" (BARROS, 1778, p. 13). De todo modo, os méritos portugueses estariam ao alcance de homens e não de heróis fabulosos. Com isso, ao passo que se restringia o crível, ampliava-se o cognoscível. Exemplo notório está no padrão encomendado por Dom Lourenço, no intuito de registrar o descobrimento de Malaca. Assim, enquanto eram verdadeiros os feitos portugueses, os dos gregos pareciam excessivamente fabulosos:

[...] e Gonçalo Gonçalves, que era o pedreiro da obra, ainda que não fosse Hércules para se gloriar dos padrões de seu descobrimento, eram estes em parte de tanto louvor, que pôs o seu nome ao pé dele, e assim fica Gonçalo Gonçalves mais verdadeiramente por pedreiro daquela coluna do que Hércules é autor de muitas que lhe os gregos dão em suas escrituras (BARROS, 1777, p. 426).

Com efeito, François Hartog lembra-nos que entre os latinos, desde Estrabão, as colunas de Hércules - ou Héracles - eram tidas como o início da Europa (HARTOG, 2003), o que nos leva a considerar que o papel histórico concreto atribuído por João de Barros a Gonçalo Gonçalves pode incorporar a noção de "autocriação do homem", oportunamente sugerida por Agnes Heller, em que o "[...] indivíduo passa a ter a sua própria história de desenvolvimento pessoal, tal como a sociedade adquire também a sua história de desenvolvimento" (HELLER, 1982, p. 9). Definitivamente, os padrões portugueses remetiam a feitos cuja glória superava aos gregos em suas curtas e seguras navegações “[...] como é de Grécia ao Rio Faso, sempre a vista da terra, jantando em um porto e ceando em outro" (BARROS, 1778, p. 360). A gente portuguesa navegaria por tantas mil léguas à vista de mouros e de tantos pagãos que viriam “[...] a ser antípodas de sua própria pátria, coisa tão nova e 
maravilhosa na opinião das gentes, que até doutos e graves barões em suas escrituras puseram em dúvida de os haver" (BARROS, 1778, p. 361). Daí a demanda de Dom Manuel em fundar um templo que correspondesse à mais notável obra jamais vista "[...] pois por ela o Mundo foi estimado em mais do que se dele cuidava antes que descobríssemos esta sua tão grande parte" (BARROS, 1778, p. 374). Tal obra haveria de ficar em lugar de evidência e prestar homenagem à mãe de Deus:

E como o lugar de Rastelo é o mais célebre e ilustre que este reino de Portugal tem, por ser nos arrabaldes de Lisboa, monarca desta oriental conquista e porta por onde haviam de entrar neste reino os triunfos dela, nesta entrada convinha ser feito, não um pórtico de pompa humana, nem um templo a Júpiter Protetor, como os romanos tinham em Roma no tempo de seu império, a que ofereciam as insígnias de suas vitórias, mas um templo dedicado àquele vivo e divino templo que é a Madre de Deus da vocação de Belém (BARROS, 1778, p. 374-375). ${ }^{10}$

Um templo à mãe de Deus e não um templo a Júpiter, uma divindade pagã, sobretudo em face da qualidade dos feitos, admiráveis não apenas pela contenda com homens de diferentes nações e seitas, mas também pela superação das forças da natureza, em que a emulação com os feitos dos antigos e de outras nações europeias é evidente:

Porque, se lemos guerras de persas, gregos, romanos ou de outras nações desta nossa Europa, nas quais houve grandes perigos no rompimento de exército com exército, trabalhos de fome e sede e vigília, na continuação de algum comprido cerco, frio e ardor do Sol na variação dos tempos e climas, grandes enfermidades por corrupção dos ares ou mantimentos e outros mil gêneros de acidentes que chegam a estado da morte, todos estes perigos $e$ trabalhos passa a nossa gente portuguesa em suas navegacões e conquistas (BARROS, 1777b, p. 143). ${ }^{11}$ 
Sem dúvida, o custo social do empreendimento foi uma questão problemática, principalmente em vista de suas implicações na conservação do reino português. Com efeito, Michel Senellart, atento às questões que envolvem o ofício do príncipe, observou que seus feitos devem ser orientados pela boa condução dos homens, tendo em vista o interesse comum e a conservação do estado. Em síntese, para Senellart, o interesse público e a conservação do estado são homogêneos à própria noção de justiça, motor fundamental das ações do príncipe (SENELLART, 2006). Diante disso, a despeito dos custos sociais, para João de Barros, os proveitos e as rendas obtidas com os descobrimentos e a construção de um império transcontinental alçaria o reino português ao mesmo patamar de outras gloriosas nações europeias. Diante disso, vale notar que a produção historiográfica de João de Barros denota todo o engajamento de um cortesão atento à celebração dos acontecimentos, de modo que a legitimidade do poder régio não seja abalada.

\section{Historiografia de corte e vicissitudes épicas}

Assim como, em Portugal, o movimento humanista foi marcado pela influência do humanismo italiano, em um primeiro momento, e pela influência do humanismo norte-europeu, em um segundo momento, é digna de nota, ainda, a presença de um elemento que marcaria a prática historiográfica das cortes em toda a Europa inclusive no reino luso -, definido a partir das reflexões acerca da escrita da história presente nos primeiros humanistas historiadores da corte aragonesa de Nápoles. Em suma, esta reflexão metodológica é marcada pela consciência do papel político que a escrita da história possui, em igualar os feitos contemporâneos às vicissitudes épicas do mundo clássico (ALBANESE, 2009).

Segundo Gabriella Albanese, somente "o primado da retórica como ciência da persuasão oculta" pôde "[...] sancionar o nascimento de uma historiografia que fosse a expressão das instituições oficiais do Estado" (ALBANESE, 2009, p. 294). Para a autora, pautada na mais recente crítica historiográfica, a historiografia humanista caracteriza-se "[...] pela celebração do principado como projeto ético-estético 
compartilhado por intelectuais engagés" (Idem). Nesse sentido, vale lembrar que João de Barros foi um historiador francamente comprometido com o governo de Dom João III, tendo ocupado cargos importantes, como o de tesoureiro do dinheiro da Casa da Índia, o de tesoureiro da Casa da Mina e o de tesoureiro-mor da Casa de Ceuta, cargos em que só deveria prestar conta de seus atos diretamente ao rei, fato que denota proximidade e lealdade ao monarca.

Com efeito, para Albanese, a proclamação da equidade entre os fatos da Antiguidade e os fatos contemporâneos pode ser compreendida como uma "declaração geral e completa dos desígnios de toda historiografia das cortes renascentistas", ou ainda:

[...] um verdadeiro e apropriado programa de escrita histórica tendo em mira enfocar privilegiadamente a valia testemunhal do historiador para a posteridade, segundo as indicações ciceronianas, e o seu papel de cogestor da política dos senhores, príncipes e reis por meio da obra historiográfica, graças ao empenho em reconhecer plena dignidade da valia dos 'facta nova ac recentiora', pelo menos igual ao da dos 'facta antiqua' (ALBANESE, 2009, p. 310).

Assim, ao passo que, por um lado, João de Barros chamava a atenção para as irreparáveis perdas humanas que os empreendimentos marítimos traziam consigo, por outro, iguala os feitos portugueses aos de outras nações, sobretudo aos daquelas que apresentam estreita relação com os antigos, em que se encontram os exemplos mais notórios da boa condução dos homens voltada aos interesses públicos e à conservação do estado. Em suma, o moderno seria sistematicamente exaltado através do antigo. É sob esta chave de leitura que podemos compreender o pronunciamento de Dom Manuel em Montemor-o-Novo diante de Vasco da Gama e ou outros capitães que o acompanhariam à Índia:

Porque, se da costa da Etiópia, que quase de caminho é descoberta, este meu reino tem adquirido novos títulos, novos proveitos e renda, que se pode esperar, indo mais adiante com este descobrimento, senão pudéramos conseguir aquelas orientais riquezas tão celebradas dos antigos escritores, 
parte das quais pelo comércio tem feito tamanhas potências, como são Veneza, Gênova, Florença e outras grandes comunidades de Itália? (BARROS, 1778, p. 273). ${ }^{12}$

Alcançar a riqueza celebrada pelos antigos. Ainda que a cobiça fosse um problema concreto apontado por João de Barros, a busca de riquezas não macula as glórias do príncipe. Pelo contrário, serve de estímulo aos feitos, sobretudo para uma aristocracia atenta à sua carreira e às suas mercês. Esta é uma perspectiva que ganha sentido quando consideramos, por exemplo, a celebração dos feitos de um fidalgo como Diogo Lopes de Sequeira, que toma “[...] posse daquela riquíssima Malaca, situada na Áurea Quersoneso, terra tão celebrada dos antigos geógrafos" (BARROS, 1777a, p. 572). Com efeito, o esplendor comercial de Malaca ganhou contornos na pena de João de Barros. Segundo Sanjay Subrahmanyam, por volta de 1500, a cidade "[...] era um dos nós principais do comércio marítimo asiático, articulado com a China e a Insulíndia Oriental, mas também com a Índia, o Golfo Pérsico e o Mar Vermelho" (SUBRAHMANYAM, 1995 , p. 19). Por sua vez, detido sobre o Livro em que dá relação do que viu e ouviu no Oriente, de Duarte Barbosa, José Carlos Vilardaga faz notar que a cidade de Malaca figura ao longo das descrições a respeito da acessibilidade às rotas comerciais locais (VILARDAGA, 2010). Assim, a compreensão da dinâmica do comércio local definia a prioridade das investidas portuguesas, daí a atenção dispensada por nosso historiador quinhentista ao assunto, que julgava ter Malaca alcançado o epíteto de áurea, "[...] por razão do muito ouro que se traz de Monancabo e Barros, que são duas comarcas onde se ele tira na Ilha de Sumatra" (BARROS, 1777a, p. 3).

Por fim, poder e riqueza não apenas caminhavam juntos, mas também eram orientados por aquilo que fora a Antiguidade. É na busca das riquezas que teriam enobrecido cidades como Veneza, Gênova e Florença, onde encontramos importante elemento de equiparação dos feitos portugueses ao de outras nações, notavelmente daquelas que, por sua história, possuíam laços mais estreitos com os antigos: não apenas por serem responsáveis pelo comércio das riquezas exaltadas pelos antigos - embora, de fato, creio que seja válida a tese de que as atividades comerciais das cidades 
italianas tenham "despertado" de um longo torpor a que haviam se entregado após a queda de Roma -, mas principalmente por serem ícones de alguns valores característicos do início da Época Moderna: enquanto Veneza e Gênova foram as mais importantes cidades comerciais ao longo dos séculos XIII, XIV e XV - sendo Veneza, ainda, importante referência política no que tange aos valores de independência e ao autogoverno ao final do século XV -, foi Florença e seu Renascimento quem deu a tônica no âmbito da cultura (BRAUDEL, 1996).

Efetivamente, a pena de João de Barros capta o peso histórico da economia veneziana. Em estudo clássico, Fernand Braudel, detido na formação das economias-mundo europeias, atenta para a superioridade de cidades como Veneza e Gênova no domínio das atividades mercantis do Mediterrâneo com o Levante. Com efeito, Braudel assinala que o pequeno comércio que se instaura desde o século IX entre as pequenas cidades situadas nas costas da Itália e as grandes cidades do Islão e Constantinopla, será responsável pela primazia comercial de Veneza ao final do século XIV, e pela de Gênova em um segundo momento. Contudo, embora cidades como Milão e Florença também tenham acompanhado toda a dinâmica comercial mediterrânica de perto, o caso veneziano é emblemático, uma vez que, desde muito cedo, conseguiu talhar seu império:

[...] modesto em extensão mas de espantosa importância estratégica e mercantil, por causa do seu alinhamento ao longo das rotas do Levante. Um Império disperso que se parece antecipadamente, guardadas as devidas proporções, com o dos portugueses ou dos holandeses, mais tarde, no oceano Índico, segundo o esquema do que os anglo-saxões chamam trading posts Empire, uma cadeia de postos mercantis que constituem, todos juntos, uma longa antena capitalista. Um Império ‘à fenícia', diremos nós (BRAUDEL, 1996, p. 104).

De fato, Braudel nos dá a dimensão do peso econômico de Veneza às vésperas da época de João de Barros, que, provavelmente, compunha o espaço mental do humanista português. 
Definitivamente, acredito ser esta reputação de potência comercial que faz eco na pena de nosso humanista: ainda que o "triunfo de Vasco da Gama" tenha deslocado as grandes vias do comércio internacional do Mediterrâneo para o oceano Atlântico, os comerciantes italianos não perderiam seu espaço nesta nova conjuntura, em que assumiriam posições decisivas, tal como ensina-nos, mais uma vez, Fernand Braudel:

Em Lisboa, quando se acaba o século XV, os comerciantes italianos formam uma colônia próspera de que conhecemos todos os grandes nomes. Também é sabido que Cristóvão Colombo ganhou Portugal a serviço dos Centurione, Spinola e di Negro, todos comerciantes genoveses. Os mais ricos desses comerciantes estiveram na origem da economia açucareira da Madeira e participaram, como os Vanni, os Gridetti ou, melhor ainda, os Machione, da equipagem de barcos inteiros, quando da viagem de Pedro Álvares Cabral (150103). Alguns desses comerciantes se acharão em seguida do outro lado do Atlântico, no Brasil, onde fizeram descendência. (BRAUDEL, 2007, p. 74).

De todo modo, não podemos perder de vista que tal perspectiva se inscrevia numa concepção de mundo orientada por equivalências entre o moderno e o antigo. $\mathrm{E}$, nesse sentido, interessa atentarmos para a eficiente comparação feita por Braudel entre venezianos e fenícios, tendo em vista que estes últimos podem ser compreendidos como um "esboço de economia-mundo", segundo o próprio autor. Entretanto, é preciso notar ainda que o declínio dos fenícios foi precedido pela ascensão de Cartago, que aos poucos dominaria a totalidade dos estabelecimentos fenícios. Essa comparação ganha ainda maior relevância quando a percebemos na pena do próprio João de Barros, visto que o historiador quinhentista compara os conflitos inerentes às conquistas portuguesas aos conflitos entre romanos e cartagineses: 
E assim estava limpa deles no tempo do Rei Dom João, o primeiro, que desejando ele derramar seu sangue na guerra dos infiéis, por haver a benção de seus avós, esteve determinado de fazer guerra aos mouros do reino de Granada e por alguns inconvenientes de Castela, e assim por maior glória sua, passou além-mar em as partes de África, onde tomon aquela Metrópole Ceuta, cidade tão cruel competidora de Espanha, como Cartago foi de Itália; da qual cidade se logo intitulou por senhor, como quem tomava posse daquela parte de África e deixava porta aberta a seus filhos e netos para irem mais avante (BARROS, 1778, p. 10-11). ${ }^{13}$

Enquanto na Antiguidade os italianos encontravam em Cartago seus cruéis competidores, entre os modernos, os ibéricos encontrariam em Ceuta seus grandes inimigos. Como apontamos anteriormente, havia uma pretensa continuidade histórica entre o mundo antigo e os modernos portugueses e, nesse sentido, é importante a consideração segundo a qual o Renascimento "[...] constrói o seu clima epocal a partir duma lógica de afinidades temporais que torna mais presente o passado distante e mais ausente o passado próximo" (BARRETO, 1986, p. 311). Com efeito, é esta perspectiva que orienta a relação entre Roma antiga e Portugal moderno apresentada de formas variadas na pena de João de Barros, para quem a grandeza dos feitos portugueses encontrava equivalência nos dos antigos. Em suma, a exaltação do moderno fundamenta-se na excelência da Antiguidade:

[...] porque não somente tomaram cidades, vilas e lugares, nos principais portos e forças dos reinos de Fez e Marrocos, restituindo à Igreja Romana a jurisdição que naquelas partes tinha perdida depois da perdição de Espanha, como obedientes filhos e primeiros capitães pela fé nestas partes de África, mas ainda foram despregar aquela divina e real bandeira da milícia de Cristo (que eles fundaram por esta guerra dos infiéis) nas partes orientais da Ásia, em meio das infernais mesquitas da Arábia e Pérsia, e de todos os pagodes da gentilidade da Índia de aquém e de além do Gange, parte 
onde (segundo escritores gregos e latinos) exceto a ilustre Semirames, Baco e o grande Alexandre, ninguém ousou cometer (BARROS, 1778, p. 11). ${ }^{14}$

Vale notar que a comparação com Alexandre O Grande prolonga a lógica de afinidades temporais para o âmbito de um ideal heroico reivindicado por João de Barros para a dinastia de Avis. Com efeito, segundo Anthony Pagden, durante séculos, Alexandre foi considerado o arquétipo do construtor de impérios por ter sido o primeiro grande imperador do ocidente: entre 336 a. C. e 323 a. C. seu império teria sido o mais extenso da Antiguidade, assegura-nos o autor. Por sua vez, além de destruir o Império Persa da dinastia Aquemênida, Alexandre conseguiria unir todos os Estados gregos independentes. Todavia, mais do que conquistar, importa notar que sua ambição foi construir um elo entre o ocidente e o oriente, enfim, entre Ásia e Europa, ou seja, helenos e bárbaros (PAGDEN, 2002).

Ora, em sua figuração do príncipe ideal, Baldassare Castiglione também nos remete a Alexandre, pois, segundo ele:

[...] não contente com a fama merecidamente conquistada por ter dominado o mundo com as armas, edificou Alexandria no Egito, Bucefália na Índia e outras cidades noutros países; e pensou dar forma de homem ao monte Atos, construindo-lhe na mão esquerda uma grande cidade e na direita uma grande taça para onde confluiriam todos os rios que nele nascem e que dali desembocariam no mar, ideia de fato grande e digna de Alexandre Magno (CASTIGLIONE, 1997, p. 301).

Em síntese, alcançar fama e fundar cidades: eram estas as qualidades que João de Barros atribuía à dinastia de Avis e, também, aos nobres portugueses, sempre em comparação com os antigos, ao tratar da constituição do império português. Sem dúvida, é o caso de nos lembrarmos da convicção humanista de que a obtenção de honra, glória e fama era a meta de todo homem virtuoso (SKINNER, 1996). Com efeito, a superação de uma situação sui generis, resultante de um feito histórico singular, exigia da Casa Real portuguesa a manutenção de suas conquistas, principalmente em face 
da diversidade de povos doravante integrados como súditos, mas que, entretanto, possuíam grande variedade de crenças e costumes. Tendo em vista que a novidade da situação é correlata à honra do príncipe em conseguir assimilar e contornar as dificuldades que se apresentavam, importa assinalar a perspectiva de Nicolau Maquiavel sobre o assunto. Para o florentino, "[...] nunca coisa nenhuma deu tanta honra a um governante novo como as novas leis e regulamentos que elaborasse". (MAQUIAVEL, 1996, p. 137). Sem dúvida, assim como João de Barros detinha uma visão positiva da religião dos antigos (MARCOCCI, 2012) em um mundo no qual Maquiavel ensinara a desvincular a prática política do juízo moral cristão, é possível sugerir, também, que o humanista português não fica atrás do pensador italiano no que tange à concepção sobre a honra do príncipe cristão. $\mathrm{Na}$ trilha das relações existentes entre João de Barros e Maquiavel, foi Martim de Albuquerque quem nos atentou para a inequívoca recepção das ideias do florentino pelo cronista português no Panegírico de Dom João III (ALBUQUERQUE, 2007), ao passo que, mais recentemente, Giuseppe Marcocci anunciou que o panegírico foi a primeira reação europeia conhecida tanto à edição dos Discursos sobre a primeira Década de Tito Livio quanto à edição de $O$ Principe (MARCOCCI, 2012).

Definitivamente, a criação de fortalezas e o estabelecimento de uma rede comercial em dimensões globais exigiu paulatina inovação por parte dos Avis: a criação de um império de entrepostos comerciais, como sugerimos com Fernand Braudel. Por sua vez, Anthony Pagden faz com que notemos que a concepção de império é derivada da palavra latina imperium, e denota, simultaneamente, tanto o poder supremo do comando bélico quanto o direito do magistrado de impor a lei em diferentes lugares. Em suma, o historiador inglês chama a atenção para o fato de que, em sua acepção original, imperium significava soberania. Sentido que se manteria intacto até o século XVIII (PAGDEN, 2002). Ora, se a definição de soberania deve passar pela compreensão histórica da formação do Estado moderno e, concomitantemente, exerceu papel importante na estruturação do ideal de soberano, seria o caso de especularmos sobre a hipótese de que a defesa que João de Barros faz da construção do império Português pode nos remeter a um discreto embate político 
interno a respeito da legitimidade da Casa de Avis, uma dinastia relativamente nova. ${ }^{15}$ De todo modo, a despeito da especulação, não podemos perder de vista a tese de que as pretensões imperialistas de Portugal pressupunham, também, a configuração da soberania dos reis portugueses no âmbito de uma jurisdição superior que possuísse autoridade junto aos soberanos locais, tal como ensina Luis Filipe F. R. Thomaz (THOMAZ, 2008).

Com efeito, importa considerar que ao início do século XV Portugal era um dos reinos mais pobres da Europa, sendo-lhe sistematicamente negado o acesso às tradicionais reservas de ouro e prata que abasteciam outros países europeus. Além disso, possuía uma capacidade comercial extremamente limitada. Diante disso, a glória de Portugal dependeria não apenas de sua capacidade de explorar os recursos de sua costa atlântica, mas sobretudo de sua experiência marítima. Efetivamente, é digno de nota que ao final do século XVII o império Português se estenderia da África Ocidental até o sul da China e abarcaria, também, a Índia (PAGDEN, 2002). É em vista disso que, nas Décadas, a nação de Vasco da Gama pode ser considerada tão gloriosa quanto a romana, tal como podemos verificar no excerto a seguir transcrito:

Por causa do qual, como adiante se dirá, o Rei acrescentou a sua Coroa os títulos que ora tem, de Senhor da Conquista, Navegação e Comércio da Etiópia, Arábia, Pérsia e Índia. E na satisfação deste grande serviço, mostrou o Rei quanto o estimava, fazendo logo e depois mercê a Vasco da Gama destas coisas: que ele e seus irmãos se chamassem de Dom, e que, no escudo das armas de sua linhagem, acrescentasse uma peça das armas reais deste reino, e o ofício de Almirante dos Mares da Índia, e mais trezentos mil reais de renda; e que em cada um ano pudesse empregar na Índia duzentos cruzados em mercadorias, os quais regularmente, na especiaria que lhe vem do emprego deles, respondem cá no reino dois contos e oito centos mil reais, e tudo isto de juros, e assim Conde da Vidigueira, correndo depois o tempo, em que as coisas da Índia mostraram ter a grandeza delas maior do que parecia nos primeiros anos. E se Vasco da 
Gama fora de nação tão gloriosa como eram os romanos, per ventura acrescentara ao apelido da sua linhagem posto que fosse tão nobre como é esta alcunha - da India, pois sabemos ser mais gloriosa coisa para insígnias de honra o adquirido que o herdado, e que Scipião mais se gloriava do feito que lhe deu por alcunha, Africano, que do apelido de Cornélio, que era da sua linhagem (BARROS, 1778, p. 371-372). ${ }^{16}$

De fato, não havia notícias entre gregos, romanos ou outra nação de feitos equivalentes aos dos portugueses regidos pelos Avis. Para João de Barros, Dom Manuel foi um instrumento por meio do qual Deus abriria as portas de um mundo de bárbaros, brutos e infiéis, cheio de riquezas que, uma vez alcançadas, estimularia louvores e incentivaria o reconhecimento das virtudes do regente por parte de seus súditos, a despeito de todas as perdas humanas e outros prejuízos. Em suma, para João de Barros, Dom Manuel foi "[...] o mais bem afortunado rei da Cristandade, pois nos primeiros dois anos de seu reinado descobrira maior estado à Coroa deste reino, do que era o património que com ele herdara" (BARROS, 1778, p. 380). Para o humanista, tal façanha era "[...] coisa que Deus não concedera a nenhum príncipe da Espanha, nem a seus antecessores que nisso bem trabalharam no decurso de tantos anos" (Idem), mas, principalmente, era um fato que não "[...] se achava escritura de gregos, romanos, ou de alguma outra nação" (Idem). Efetivamente, é característico na historiografia humanista do alvorecer da Época Moderna a projeção de um império cristão que corresponda a um império passado (GÜNTHER, 2013). Em vista disso, creio que João de Barros dá embasamento suficiente ao humanista espanhol Juan Luís Vives, quando este argumentou que nem os homens do seu tempo eram anões nem os da Antiguidade eram gigantes (LE GOFF, 2003): enfim, homens excepcionais, os portugueses, regidos por um soberano cristão afeito à promoção do bem público, seriam sujeitos no curso de sua própria história. Para o historiador quinhentista, ao fazer o que os próprios antigos fizeram, os portugueses iriam além.

Por fim, na pena de um moralista, sua narrativa histórica haveria de figurar como uma clara demonstração da própria ciência moral. Sem a confirmação da história, o preceito moral incorreria na mais 
absoluta vanidade (GARIN, 1993), ao passo que o hiato existente entre a efetividade histórica e os preceitos morais definiria o distanciamento necessário à percepção da noção de moderno. Em suma, efetividade histórica e mediação convergiriam para o plano político, espaço de embates e definição de posições que se desenham a partir do estreito vínculo estabelecido entre antigos e modernos.

\section{Considerações finais}

Em suas Décadas da Ásia, é notório o esforço de João de Barros em contrapor os exemplos, as experiências e as instituições da Antiguidade, aos exemplos, às experiências e às instituições portuguesas de sua época, para, a partir daí, perceber as configurações de seu próprio mundo. Sem dúvida, essa percepção do humanista português extrapola sua especificidade e pode ser considerada uma das mais notórias evidências do pensamento histórico e da prática historiográfica da Época Moderna. Com efeito, este procedimento permite a atualização e a apropriação de tradições intelectuais que possibilitam sistemáticas e eficientes comparações diante de uma necessária autonomia do juízo em face de tomadas de decisões ímpares.

No caso de Portugal, essas decisões definem-se no âmbito de sua experiência ultramarina. Sem dúvida, a vertente ibérica da querela entre antigos e modernos está atrelada a essa experiência, mas também à demanda de formular um horizonte histórico eficiente para estabelecer comparações, sua intrínseca necessidade de reconfigurar paradigmas e, ainda, à Retórica, elemento basilar do aparato historiográfico humanista. Além disso, a concepção de um mundo orientado por equivalências entre antigos e modernos, associada à consciência do papel político que a escrita da história possuía em igualar os feitos contemporâneos às vicissitudes épicas do mundo clássico, permitiria a formulação de uma continuidade artificial entre os antigos e os modernos portugueses, onde estes alcançavam méritos de magnitude similar, o que permitia a projeção de um império cristão correspondente a um império passado. Por fim, era na tessitura da relação entre antigos e modernos que se assentava, ainda, a legitimidade de um soberano afeito à promoção do bem público. 


\section{HISTORY AND MORAL SCIENCE IN $D E ́ C A D A S$ BY JOÃO DE BARROS: THE RELATIONSHIP BETWEEN ANCIENTS AND MODERNS}

Abstract: The purpose of this article is to revisit the dispute between Ancients and Moderns in the book Décadas da Ásia written by João de Barros. Published between the years 1552 and 1563, this work can be defined as the most notorious attempt to set a global direction for the phenomenon of the Portuguese maritime discoveries. However, when addressing the origins and maturation process of maritime expansion in Portugal, the Décadas da Ásia brings the early part of the Iberian clash between Ancients and Moderns. Thus, our interest is to recover this struggle within the relationship that João de Barros establishing between Ancients and Moderns, as a presupposition of historical thought in the early Modern Era.

Keywords: History of historiography. Humanism. João de Barros. Ancients and Moderns. Portugal.

\section{Notas}

${ }^{1}$ Segundo António Rosa Mendes, a "geração de Quinhentos" compreende, sobretudo, nomes como André de Resende, Dom João de Castro, Garcia de Orta, Pedro Nunes, Damião de Góis, André de Gouveia, o próprio Dom João III e o "decano" João de Barros.

2 Agradeço esta observação a Maria Lêda Oliveira.

${ }^{3}$ As informações das Décadas referem-se invariavelmente às edições de 1777 e 1778 que constam arroladas nas referências ao final do artigo. Nas transcrições optamos pela atualização da grafia, uma vez que, para nosso propósito, o valor semântico das palavras não fica comprometido.

${ }^{4} \mathrm{O}$ grifo é meu.

${ }^{5} \mathrm{O}$ grifo é meu.

${ }^{6} \mathrm{O}$ grifo é meu.

${ }^{7} \mathrm{O}$ grifo é meu.

${ }^{8} \mathrm{O}$ grifo é meu.

${ }^{9} \mathrm{O}$ grifo é meu.

${ }^{10} \mathrm{O}$ grifo é meu.

${ }^{11} \mathrm{O}$ grifo é meu.

${ }^{12} \mathrm{O}$ grifo é meu.

${ }^{13} \mathrm{O}$ grifo é meu. 
${ }^{14} \mathrm{O}$ grifo é meu.

${ }^{15}$ A especulação está calcada em nossa leitura da bibliografia: tendo como ponto de partida a Crônica da Tomada de Ceuta, de Gomes Eanes de Zurara, Luís Filipe F. R. Thomaz e Jorge Santos Alves sugerem que a primeira fase da expansão portuguesa, ao contar com o beneplácito pontifício das bulas papais, almejava "a um tempo a pacificação social do reino e sua promoção aos olhos da Europa”. Além disso, os autores atentam também para o empenho de Zurara em "conseguir os efeitos que cobrem de honra e de valor o conjunto da geração de Avis". Em suma, filho de Dom João I, fundador da Dinastia de Avis, o infante Dom Henrique é sobrevalorado na perspectiva de Thomaz e Santos (THOMAZ; ALVES, 1991, p. 85-86. O grifo é meu). Nesse sentido, é significativo o papel histórico atribuído ao infante como precursor das grandes navegações: para Luís Filipe Barreto, por exemplo, "[...] o objeto e objetivo essencial de Zurara é o Infante enquanto causa fazedora próxima da apropriação da Guiné. O Infante é o motor da nova historicidade e destino de Portugal' (BARRETO, 1983, p. 71). O próprio João de Barros entende o infante Dom Henrique como o verdadeiro iniciador de "[...] tão ilustre empresa, como foi o descobrimento e conquista que deu fundamento a esta nossa Ásia” (BARROS, 1778, p. 15). Por fim, importa recuperarmos o que escreveu Maria Helena da Cruz Coelho a respeito da consolidação da Dinastia de Avis: "Dom João I percebe-se de que a consolidação da sua dinastia e a segurança do reino se jogavam não só em terra, mas sobretudo no mar. Em terra, procurou contrabalançar o poderio castelhano por entre guerras e acordos de paz que outras ameaças laterais a Castela, como o reino de Aragão e o de Granada, ajudariam a concretizar. No mar apostou numa estratégia mais envolvente de defesa e expansão do reino, como resolução das suas crises internas e externas". (COELHO, 1998. p. 131. O grifo é meu). Deixo aqui meu agradecimento à generosidade de Fernando Altoé, que me cedeu parte das transcrições. ${ }^{16} \mathrm{O}$ grifo é meu.

\section{Referências}

ALBANESE, Gabriella. A redescoberta dos historiadores antigos no Humanismo e o nascimento da historiografia moderna. Valla, Facio e Pontano na corte napolitana dos reis de Aragão. In: PIRES, Francisco Muraria (Org.). Antigos e modernos: diálogos sobre a (escrita da) história. São Paulo: Alameda, 2009.

ALBUQUERQUE, Martim de. Maquiavel e Portugal. Estudo de História das idéias políticas. Lisboa: Alêthia Editores, 2007. 
BARRETO, Luís Filipe. A Ásia na cultura portuguesa (c. 1485-c. 1630)". In: CUNHA, Mafalda Soares et al. Os construtores do Oriente Português. Porto: Edifício da Alfândega: Comissão Nacional para a Comemoração dos Descobrimentos Portugueses: Câmara Municipal do Porto, 1998.

. Caminhos do saber no Renascimento português. Estudos de história e teoria da cultura. Lisboa: Imprensa Nacional/Casa da Moeda, 1986.

- Descobrimentos e Renascimento: formas de ser e pensar nos séculos XV e XVI. Lisboa: Imprensa Nacional/Casa da Moeda, 1983.

BARRETO, Vicente de Paulo; CULLETON, Alfredo (Coord.). Dicionário de Filosofia Política. São Leopoldo: Ed. UNISINOS, 2010.

BARROS, João de. Da Asia de João de Barros e de Diogo de Couto. Da Asia de João de Barros dos feitos que os portugueses fizeram no descobrimento dos mares e terras do Oriente. Decada Primeira. Parte Primeira. Nova Edição oferecida a sua Magestade D. Maria I. Rainha Fidelíssima. Lisboa: Na Régia Officina Typografica, 1778.

. Da Asia de João de Barros dos feitos que os portugueses fizeram no descobrimento dos mares e terras do Oriente. Decada Primeira. Parte Segunda. Lisboa: Na Régia Officina Typografica, 1777.

- Da Asia de João de Barros dos feitos que os portugueses fizeram no descobrimento dos mares e terras do Oriente. Decada Segunda. Parte Primeira. Lisboa: Na Régia Officina Typografica, 1777a.

- Da Asia de João de Barros dos feitos que os portugueses fizeram no descobrimento dos mares e terras do Oriente. Decada Segunda. Parte Segunda. Lisboa: Na Régia Officina Typografica, $1777 \mathrm{~b}$.

- Da Asia de João de Barros dos feitos que os portugueses fizeram no descobrimento dos mares e terras do Oriente. Decada Terceira. Parte Primeira. Lisboa: Na Régia Officina Typografica, 1777c.

- Da Asia de João de Barros dos feitos que os portugueses fizeram no descobrimento dos mares e terras do Oriente. Decada Terceira. Parte Segunda. Lisboa: Na Régia Officina Typografica, $1777 \mathrm{~d}$.

BRAUDEL, Fernand. Civilização material, economia e capitalismo, séculos XV-XVIII. O tempo do mundo. Tradução de Telma Costa. São Paulo: Martins Fontes, 1996.

. O modelo italiano. Tradução de Franklin de Mattos. São Paulo: Companhia das Letras, 2007.

CARVALHO, Joaquim Barradas de. As fontes de Duarte Pacheco Pereira no 'Esmeraldo de Situ Orbis'. In: Coleção da Revista de História (PAULA, E. Simões de. (Dir.). São Paulo: Universidade de São Paulo, 1967. 


\section{Rubens Leonardo Panegassi}

CASTIGLIONE, Baldassare. O cortesão. Tradução de Carlos Nilson Moulin Louzada. São Paulo: Martins Fontes, 1997.

CASTRO, Aníbal Pinto de. Retórica e teorização literária em Portugal. Do humanismo ao Neclassicismo. Coimbra: Atlantida, 1973.

COELHO, António Borges. Tudo é mercadoria: Sobre o percurso e obra de João de Barros. Alfragide: Editora Caminho, 1992.

COELHO, Maria Helena da Cruz. Na Barca da conquista, o Portugal que se fez caravela e nau. In: NOVAES, Adauto (Org.). A Descoberta do homem e do mundo. São Paulo: Companhia das Letras, 1998.

DIAS, José Sebastião da Silva. Influencia de los Descubrimientos en la vida cultural del siglo XVI. Tradução de Jorge Rueda de La Serna. México: Fondo de Cultura Económica, 1986.

ELLIOTT, J. H. O velho mundo e o novo 1492-1650. Tradução de Maria Lucília Filipe. Lisboa: Querco, 1984.

FEBVRE, Lucien. O problema da incredulidade no século XVI: a religião de Rabelais. Tradução de Maria Lúcia Machado. Tradução dos trechos em latim de José Eduardo dos Santos Lohner. São Paulo: Companhia das Letras, 2009.

FUMAROLI, Marc. La Querelle des Anciens et des Modernes. XVII ${ }^{\mathrm{e}} \mathrm{XIII}{ }^{\mathrm{e}}$ siècles. Paris: Gallimard, 2001.

GARIN, Eugenio. L'umanesimo italiano. Filosofia e vita civile nel Rinascimento. Roma: Editori Laterza, 1993.

GÜNTHER, Horst. Pensamento histórico no início da Idade Moderna. In: KOSELLECK Reinhardt et alii. O conceito de História. Tradução de René E. Gertz. Belo Horizonte: Autêntica Editora, 2013.

HARTOG, François. Anciens, Modernes, Sauvages. Paris: Galaad, 2005.

. Os antigos, o passado e o presente. Tradução de Sonia Lacerda et alii. Brasília: Editora da Universidade de Brasília, 2003.

HAZARD, Paul. Crise da consciência europeia. Tradução de Óscar Lopes. Lisboa: Edições Cosmos, 1948.

HELLER, Agnes. O Homem do Renascimento. Tradução de Conceição Jardim e Eduardo Nogueira. Lisboa: Editorial Presença, 1982.

HOLANDA, Sérgio Buarque de. Visão do paraíso: os motivos edênicos no descobrimento e colonização do Brasil. São Paulo: Brasiliense/Publifolha, 2000.

KANTOR, Íris. Antigos e Modernos na historiografia acadêmica portuguesa e brasílica, cronografias e representações do passado (1720-1724). In: PIRES, 
Francisco Murari (Org.). Antigos e modernos: diálogos sobre a (escrita da) história. São Paulo: Alameda, 2009.

LE GOFF, Jaques. História e memória. Tradução de Bernardo Leitão et alii. Campinas: Editora da Unicamp, 2003.

MAQUIAVEL, Nicolau. O Príncipe. Escritos Políticos. Tradução de Lívio Xavier. São Paulo: Editora Nova Cultural, 1996.

MARAVALL, José Antonio. Antiguos y Modernos. Visión de la historia e idea de progreso hasta el Renacimiento. Madrid: Alianza Editorial, 1986.

MARCOCCI, Giuseppe. A consciência de um Império. Portugal e o seu mundo (sécs. XV-XVII). Coimbra: Imprensa da Universidade de Coimbra, 2012.

MENDES, António Rosa. A vida cultural. In: MATTOSO, José. (Dir.). MAGALHÃES, Joaquim R. (Coord.) História de Portugal. No alvorecer da modernidade. Lisboa: Editorial Estampa, 1998.

PAGDEN, Anthony. Povos e impérios: uma história de migrações e conquistas, da Grécia até a atualidade. Tradução de Marta Miranda O’Shea. Rio de Janeiro: Objetiva, 2002.

PEREIRA, Belmiro Fernandes. Antigos e Modernos: o humanismo norte-europeu nas retóricas peninsulares do séc. XVI. Península. Revista de Estudos Ibéricos. n. 5, p. 93-101, 2008.

POCOCK, J. G. A. El momento maquiavélico. El pensamiento político florentino y la tradición republicana atlántica. Tradução de Marta Vázquez-Pimentel y Eloy García. Madrid: Editorial Tecnos, 2008.

RÉVAH, Israel Salvador. 'Antiquité et christianisme', 'anciens et modernes' dans l'oevre de João de Barros. In: Revue philosophique de la France et de l'étranger. n. 92, Paris, 1967. p. 165-185.

SCHULZE, Hagen. État et nation dans l'Histoire de l'Europe. Traduit par Denis-Armand Canal. Paris: Éditions du Seuil, 1996.

SENELLART, Michel. As artes de governar: do regimen medieval ao conceito de governo. Tradução de Paulo Neves. São Paulo: Ed. 34, 2006.

SKINNER, Quentin. As fundações do pensamento político moderno. Tradução de Renato Janine Ribeiro e Laura Teixeira Motta. São Paulo: Companhia das Letras, 1996.

SUBRAHMANYAM, Sanjay. O Império Asiático Português 1500-1700. Uma história Política e Econômica. Tradução de Paulo Jorge Sousa Pinto. Lisboa: Difel, 1995.

THOMAZ, Luís Filipe F. R.; ALVES, Jorge Santos. Da cruzada ao Quinto Império. In: BETHENCOURT, Francisco; CURTO, Diogo Ramada (Org.). A memória da nação. Lisboa: Livraria Sá da Costa Editora, 1991. 


\section{Rubens Leonardo Panegassi}

THOMAZ, Luís Filipe F. R. A ideia imperial manuelina. In: DORÉ, Andréa Carla et alii (Org.). Facetas do império na história: conceitos e métodos. São Paulo: Aderaldo \& Rothschild/Brasília: Capes, 2008.

VILARDAGA, José Carlos. Lastros de viagem: expectativas, projeções e descobertas portuguesas no Índico (1498-1554). São Paulo: Annablume, 2010.

Recebido em: 19/11/2013. Aprovado em: 26/03/2014. 
